\title{
Trust-A Catalyst to Knowledge Transfer: Contemporary Studies
}

\author{
Sheikh Shamim Hasnain \\ University of Bedfordshire, UK
}

\begin{abstract}
This is a literature based paper addressing the contemporary studies on the impacts of trust on knowledge transfer. Knowledge transfer is one of the important elements of knowledge management process. Knowledge transfer helps organisations achieve competitive advantages and organisations may formulate new strategies to adjust themselves with the dynamic business environments. Trust works as a lubricant between the knowledge transfers and the knowledge recipients. It is unfortunate to note that many knowledge management gurus have ignored to study this catalyst's influences on knowledge transfer. This paper has made an endeavour to assemble the vital studies on these issues. Future researchers may empirically study the impact of trust on knowledge transfer in numerous contexts with a view to redressing the huge gray areas on these issues.
\end{abstract}

Key Words: Knowledge Management, Knowledge Transfer, Trust

\section{INTRODUCTION}

Though knowledge transfer encounters numerous barriers (Hasnain \& Jasimuddin, 2012), but trust may play an essential role in the smooth transferring of knowledge between the knowledge transfers and the knowledge recipients (Ngah, Hoo, \& Ibrahim, 2008). Rolland and Chauvel (2000) claim, "trust is, after all, the single most important precondition for knowledge exchange" (p. 239). Davenport and Prusak (1998) find that trust has a positive influence on inter-organisational knowledge transfer. They continue by arguing that, "trust can trump the other factors that positively affect the efficiency of knowledge market. Without trust, knowledge initiatives will fail, regardless of how thoroughly they are supported by technology and rhetoric and even if the survival of the organisation depends on effective knowledge transfer" (p. 34). However, unfortunately, many knowledge management gurus (Scarbrough, 1995; Taiwana, 2002; Nonaka, \& Takeuchi, 1995; Hasnain, 2016) hardly examined the issues of trust and knowledge management. Davenport and Prusak (1998) emphasise on the importance of the knowledge market in the organisation. They also chalked out three-point trust approaches, that trust must be visible, that is, people in the organisation must see that credit is given for knowledge sharing, trust must be ubiquitous and trustworthiness must start at the top, for operations and engagement of the knowledge market.

\section{MAJOR KNOWLEDGE TRANSFER AND TRUST STUDIES LISTED}

Researchers (Hansen, 2002; Lucas, 2005; Holstle and Fields, 2005; Levin, Whiterner and Cross, 2006; Nahapiet and Ghoshal, 1998; Tsai and Ghoshal, 1998; Ashleigh, Connell \& Klein, 2003; Usoro, Sharratt, Tsui, \& Shekhar, 2007; Li, 2005; Abrams, Cross, Lesser and Levin, 2003; Staples and Webster, 2008; Renzl, 2008) have examined the role of trust in knowledge transfer in different situations. Major studies on the influence of trust on knowledge transfer are briefly amplified below: 


\section{Usoro, Sharratt, Tsui, \& Shekhar (2007)}

Usoro et al. (2007) studied the role of trust in knowledge transfer within the context of virtual communities of practice. They put trust into the three dimensions of competence, integrity and benevolence, with knowledge sharing to make it operational. The investigation was carried out through surveying an intra-organisational global virtual community of practitioners. Results found that all these three dimensions of trust are positively related with knowledge sharing. Their study further found that trust based on the perceived integrity of the community is a more significant predictor of knowledge sharing than competence and benevolence based trust. Finally, Usoro et al. (2007) recommended the encouragement of integrity based trust for knowledge sharing behaviour in on-line communities of practice

\section{Lucas (2005)}

Lucas (2005), in his research study based on social information processing theory, examined the impact of trust and reputation on the transfer of best practice. Data were collected from respondents of an electricity generation company listed in Fortune 500. The influence of trust, and the provider's and recipient's reputation on the transfer was investigated. His study found that trust and reputation have a significant and positive impact on knowledge transfer. Lucas drew three conclusions by stating, "one, there is an important role for developing trust if knowledge transfer efforts are to be successful. Second, the reputation of the provider is important to recipients because they want to ensure that promises will not be broken. Third, the reputation of the knowledge recipients is similarly important because the results of these efforts are indeterminate and much is at stake" (p. 95). Trust and reputation grow over a considerable period of time. The protection of these two ensures better knowledge transfer.

\section{Ashleigh, Connell and Klein (2003)}

Ashleigh et al. (2003) used the context of communities of practice to establish a model linking knowledge transfer and trust. They identified four components of trust, namely, trust in knowledge or expertise and skills of a community or an individual, trust in capacity or the degree to which the individual may use the knowledge, trust in values, or the degree to which an individual or community possesses one's values, trust in integrity, and the degree of honest and decent behaviour of an individual or community. They also pointed out that trust is the aggregate of these four components. Their model is a two-way traffic approach, exhibiting the increase of knowledge transfer for trust and the increase of trust for knowledge transfer. They have articulated the following characteristics of the model (p. 11):

- Other things being equal, greater trust between individuals promotes the greater sharing of knowledge between them

- The extent of the promotion of knowledge sharing by trust, and its dependence on particular trust components, is context dependent.

- In particular, dependent on context, thresholds of particular trust components exist, below which trust can not be said to exist, and knowledge sharing will be minimal

- Other things being equal, greater shared knowledge between individuals promote greater trust between them.

- The extent of the promotion of trust by shared knowledge is context-dependent

- In particular, the extent to which the various components of trust will be promoted is dependent on the knowledge shared, and context.

\section{Singh and Premarajan (2007)}

Singh and Premarajan (2007) tried to find out the effect of trust and culture on tacit and explicit knowledge transfer. 125 employees from eleven software companies participated in their study. The study examined the relationship of knowledge transfer with trust and culture. 
The investigation concentrated on three types of knowledge, namely, product, expert, and ambiguous knowledge. Sharing culture, adaptation culture, sharing trustworthiness and adaption trustworthiness were used as the independent variables. The result found that sharing and adaptation trustworthiness and sharing and adaption culture are about positive relationships with tacit and explicit knowledge transfer.

\section{Holste and Fields (2010)}

This study examined the relationship of affect and cognitive based trust with sharing and use of tacit knowledge. The concept of affect based and cognitive based trust was drawn from McAllister (1995). McAllister (1995) found affirmative considerations and feelings about colleagues to be affect based trust, while faith in the competencies and reliabilities of colleagues was identified as cognitive based trust. Holste and Fields ( 2010) studied the relationship of these two types of trust with tacit knowledge sharing. The examination was done on a non-profit service organisation which has 5000 managerial and professional staff working in 185 countries in the world. Holste and Fields' (2010) results suggested that adequate levels of both affect-based and cognitive based trust are required for managers and professionals to be willing to share and use tacit knowledge. However, while affect based trust would be relatively high for colleagues when an individual works well (positive referent), willingness to use tacit knowledge depends more heavily on trust in the competence and reliability of the performance of these co-workers. Likewise, even though less liked coworkers may command adequate levels of cognitive-based trust in their competence and reliability, the willingness of professionals to share tacit knowledge with these colleagues depends heavily on an increased level of trust within the interpersonal relationship" (p. B6).

\section{Renzl (2008)}

This study investigated how interpersonal trust and knowledge sharing works. Documentation of knowledge and fear of losing one's unique value have a mediating role in knowledge sharing. The author made an in-depth study on trust in management, and its impact on knowledge sharing by squeezing fear and getting better knowledge documentation. Data were collected from two companies. One of the firms was from a utility industry, and the other was in the software consulting industry. In-depth interviews with project engineers and managers were conducted, and questionnaires were also circulated. It found that, "trust in management reduces the fear of losing one's unique value in knowledge sharing process" (p. 216) and improves willingness to document knowledge. The findings of this research have a significant impact at the managerial and theoretical levels. For managers, this research could highlight the importance of the individual's role in the knowledge sharing process. On a theoretical level, Renzl (2008) argues that, "this study provides empirical evidence for two ways in which trust has an impact on knowledge sharing; reducing fear of losing one's unique value, and improving knowledge documentation." (p. 216). Renzl (2008) also recommended a trusting relationship among all members, to establish a knowledge-friendly culture for the smooth flow of important knowledge in the organisation.

\section{Levin, Cross, Abrams and Lesser (2002)}

In their study at the IBM Institute for Knowledge-Based Organisations (IKO), the strength of the relationship between the knowledge seeker and the source, the difference between competence and benevolence-based trust, and the type of knowledge being shared was examined. Their study termed trust as the 'magic ingredient' which link and tie knowledge sharing. The study, a two-part survey of 138 people in three companies, concentrated on, "how trust affects knowledge sharing and individual evaluate the trustworthiness of others when 
seeking knowledge". The study found that competence based and benevolence trust can exist independently, that trust can develop between individuals even when there is infrequent interaction or weak ties, and "when the level of trust remained constant, survey respondents suggested that weak ties actually lead to more valuable knowledge than strong ties" (p. 3), Additionally it was found that the tacit nature of competence-based trust has great influence on knowledge transfer, while codified competence-based trust has less importance. The benevolence type of trust has a significant role in both explicit and tacit knowledge transfer, and knowledge seekers depend upon certain factors to determine the trustworthiness of an individual. It depends on the type of trust (competence or benevolence-based) with which they are going to engage with the individual. For the determination of competence-based trust the following three attributes are important; firstly a common language, or the extent to which the knowledge source and seeker understand each other and use similar jargon and terminology. Secondly a common vision, or the extent to which a knowledge source and seeker have shared goals, concerns and purpose, and thirdly, discretion or the extent to which the knowledge source is viewed as keeping sensitive source information confidential. For the determination of benevolence-based trust, with the above factors additionally they annexed two more factors of receptivity, or the extent to which the knowledge source is a good listener, and strong ties, or the extent to which the knowledge seeker and source converge frequently with each other and have a close relationship. Finally, Levin, Cross, Abrams and Lesser (2002) concluded the study, by suggesting some actions for managers to help build trust among individuals; to create a common understanding of how the business works, and to demonstrate trust building behaviours and bringing people together.

\section{Nahapiet and Ghoshal (1998)}

Nahapiet and Ghoshal (1998) developed a model on "social capital in the creation on intellectual capital". Social capital is put under three dimensions, structural, like network ties and configuration and appropriate organisation, cognitive such as shared codes, language, and narratives, and relational, such as trust, norms, obligations and identification. Nahapiet and Ghoshal (1998) claimed that, "relational dimension of social capital influences three of the conditions (shown in Figure-2.11) for exchange and combination, in many ways. These are access to parties for exchange and combination, and the motivation of parties to engage in knowledge creation through exchange and combination" (p. 254).

Nahapiet and Ghoshal (1998) continued by claiming that:

- C1 (in figugure-1): Where relationships are high in trust, people are more willing to engage in social exchange in general, and cooperative interaction in particular.

- C2 (in figure-1): Trust may also indicate greater openness to the potential for value creation through exchange and combination.

- C3 (in figure-1): Trust may both open up access to people for the exchange of intellectual capital.

- Their model is established on the social point of view. It has connected trust and knowledge sharing. 
Figure-1: Social capital with combination, exchange and creation of intellectual capital (Nahapiet and Ghoshal, 1998, p. 251)

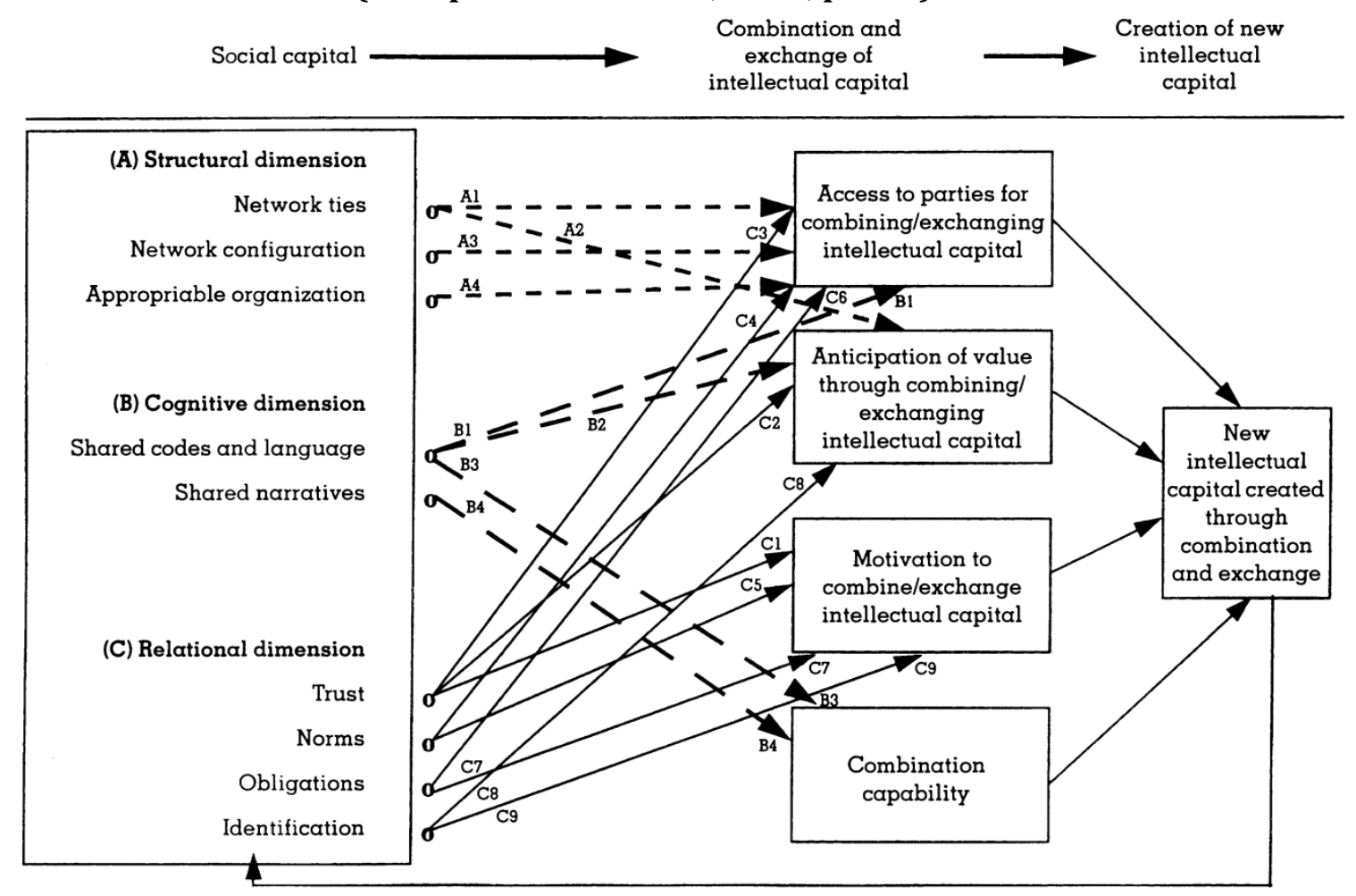

\section{Ko (2010)}

Ko (2010) investigates the role of trust-antecedents, competence and benevolence based, on knowledge transfer between consultants and functional specialists. Survey data were collected from a total of 80 projects from 71 client organisations, and 36 consulting firms. He borrowed the competence and benevolence based trust items from McAllister (1995), and for knowledge transfer, he newly developed the scales. The results found that benevolence based trust has a significant role in knowledge transfer, while competence based trust does not. Finally he concluded the study by emphasizing the development of 'personal trust', or benevolence based trust, for successful completion of projects.

\section{Levin and Cross (2004)}

Levin and Cross (2004) surveyed a total 127 respondents - 42 from a pharmaceutical company, 41 from a bank, and 44 from an oil company to propose and examine a model two party, or dyadic, knowledge exchange. Results showed that the link between strong ties and receipt of useful knowledge is mediated by competence and benevolence based trust. Once they controlled these two trustworthiness dimensions, the structural benefits of weak ties emerged. They found that competence and benevolence based trust have positive relationships with knowledge transfer.

\section{Sankowska (2013)}

Sankowska (2013) presents empirical evidence on the relationship between organisational trust, knowledge transfer, creation and innovativeness at the firm level. Total 202 surveys were conducted among the Polish companies listed on the Warsaw Stock Exchange. Sankowska (2013) finds "knowledge creation partially mediates the relationship between trust and innovativeness; and knowledge transfer partially mediates the relationship between trust and knowledge creation" (p.85). 


\section{Sreckovic \& Windsperger (2012)}

Sreckovic \& Windsperger (2012) examine the impact of trust on selecting the knowledge transfer mechanisms in cluster relationship on 118 companies in the Italian textile and fashion sector. They find that experience based trust increases knowledge sharing between the cluster partners by increasing the face-to-face knowledge transfer mechanisms. Further, it also reveals that tacitness determines the selection of the mechanisms of knowledge transfer.

Table -1: Miscellaneous Studies on Knowledge transfer and trust

\begin{tabular}{|c|c|}
\hline Researcher (s) & Remarks \\
\hline Evaristo (2007) & $\begin{array}{l}\text { A process model of knowledge transfer } \\
\text { across border is planned based on expectation. Shows how } \\
\text { trust is injured by expectation and ultimately the performance } \\
\text { of knowledge sharing is affected. }\end{array}$ \\
\hline $\begin{array}{l}\text { Becerra, Lunnan and } \\
\text { Huemer (2008) }\end{array}$ & $\begin{array}{l}\text { They examined how knowledge sharing and alliance success } \\
\text { depend on the degree of the perception of trustworthiness and } \\
\text { the willingness to take risk between the alliance partners. } \\
\text { "The results show that the transfer of tacit versus explicit } \\
\text { knowledge have very different trust and risk profiles. Whereas } \\
\text { explicit knowledge is closely associated with the firm's } \\
\text { willingness to take risk, tacit knowledge is intimately related } \\
\text { to high trustworthiness" ( Becerra et al., 2008, p. 691). }\end{array}$ \\
\hline Cheng, Yeh and Tu (2008) & $\begin{array}{l}\text { The research model was developed with 13-hypothesises } \\
\text { (nine constructs, where trust is a mediating construct). Result } \\
\text { finds that trust is a vital factor influencing inter- } \\
\text { organisational knowledge transfer. }\end{array}$ \\
\hline $\begin{array}{l}\text { Bakker, Leenders, Gabbay, } \\
\text { Kratzer and Engelen( 2006). }\end{array}$ & $\begin{array}{l}\text { Their research was to study if trust really explains knowledge } \\
\text { sharing relationship or some other factors work on the } \\
\text { process in new product development projects. Bakker et al. } \\
\text { (2006) find "trust is a poor explanatory of knowledge sharing. } \\
\text { Team membership, on the other hand, has the largest effect on } \\
\text { the density of knowledge sharing relationships. Social capital } \\
\text { thus does not reside in trust but in team membership, specially } \\
\text { for long-lived teams" (p. 594). They reveal that competence } \\
\text { based trust is having negative impact on knowledge transfer. }\end{array}$ \\
\hline Ma, Qi and Wang ( 2008) & $\begin{array}{l}\text { An empirical study on the influence of some important } \\
\text { contextual factors that affect knowledge sharing within } \\
\text { project teams at the Chinese construction sector located in } \\
\text { China. They find "trust is positively related to knowledge } \\
\text { sharing but justice, leadership style, and empowerment do not } \\
\text { influence whether employees will share knowledge among } \\
\text { themselves in project teams" (p. 97). }\end{array}$ \\
\hline $\begin{array}{l}\text { Ardichvili, Page and } \\
\text { Wentling (2003) }\end{array}$ & $\begin{array}{l}\text { Their empirical study of motivation and barriers to } \\
\text { knowledge transfer to employee participation in virtual } \\
\text { knowledge sharing communities of practice at Caterpillar Inc. } \\
\text { finds that integrity and competence based trust have influence } \\
\text { on knowledge transfer }\end{array}$ \\
\hline Tsai and Ghoshal (1998) & $\begin{array}{l}\text { The examination on all the business units of a large } \\
\text { multinational electronic company could find that benevolence } \\
\text { trusting relationship is positively associated with knowledge } \\
\text { transfer }\end{array}$ \\
\hline
\end{tabular}




\begin{tabular}{|l|l|}
\hline Gefen (2004) & The survey carried out in the companies that were involved in \\
a new Enterprise Resource Planning (ERP) with the onsite \\
assistance of a certain customization. The study could find \\
that competence based trust and benevolence based trust \\
improve the relationships between the consultants and the \\
functional experts.
\end{tabular}

\section{CONCLUSION AND FUTURE RESEARCH}

Trust is one of the important catalysts to knowledge transfer. Many researchers have investigated the impacts of trust on knowledge transfer. Sreckovic \& Windsperger (2012)

find that experience based trust increases knowledge sharing in the Italian textile sector. Sankowska (2013) finds "knowledge creation partially mediates the relationship between trust and innovativeness; and knowledge transfer partially mediates the relationship between trust and knowledge creation" (p.85). Usoro et al. (2007) find that integrity based trust has more influence on knowledge transfer than competence or benevolence based trust, while Ko (2010) finds that benevolence based trust has significant impacts on knowledge transfer than competency based trust between the consultants and the functional specialists. Holstle and Fields (2010) reveal that enough affect-based and cognitive based trust is necessary for knowledge transfer between the professionals and the managers. Lucas (2005) finds that trust and reputation have positive impact on knowledge transfer. Ashleigh et al. (2003) find thattrust increases knowledge transfer and vice versa. Singh and Premarajan (2007) reveal that sharing and adaptation trustworthiness and sharing and adaption culture are about positive relationships with tacit and explicit knowledge transfer. Similarly, many researchers (Renl, 2008; Levin et al., 2002; Levin and Cross,2004; Evaristo, 2007; Becerra et al. 2006; Ma et al., 2008; Cheng et al., 2008; Bakkar et al., 2006; Ardichvili et al., 2003; Tsai and Ghoshal, 1998; Genfen, 2004) studied the influence of trust on knowledge transfer in numerous contexts. It may be noted that most of the researchers in numerous contexts could find that trust have positive influence on knowledge transfer.

Future researchers may empirically examine the impact of different types of trust on different types of knowledge transfers in different contexts.

\section{References}

Abrams, L.C., Cross, R.., Lesser, E. \& Levin, D.Z. (2003). Nurturing interpersonal trust in knowledge-sharing networks. Academy of Management Executive,17 (4), 64-77.

Ardichvili, A., Page, V. \& Wentling, T. (2003). Motivation and barriers to participation in virtual knowledgesharing communities of practice. Journal of Knowledge Management, 7(1), 64-77.

Ashleigh, M., Connell, C. \& Klein, J. H. (2003, October). Trust and knowledge transfer: An explanatory framework for identifying relationships within communities of practice. The EIASM Second Workshop on Trust Within and Between Organisations, Amsterdam.

Bakker, M., Leenders, T. A. J., Gabbay, S. M., Kratzer, J. \& Engelen, J. M. L.V. (2006). Is trust really social capital? Knowledge sharing in product development projects. The Learning Organization, 13 (6), 594-605.

Barber, B. (1983). The Logic and Limits of Trust. NJ: Rutgers University Press.

Becerra, M., Lunnan, R. \& Huemer, L. (2008). Trustworthiness, risk and transfer of tacit and explicit knowledge between alliance partners. Journal of Management Studies, 45(4), 691-713.

Beckman,T.H.(1999) 'The current state of knowledge management', in Liebowitz,J.(ed.) Knowledge Management Handbook. NJ :CRC Press Inc., pp.1-1

Bennis, W. G. \& Nanus, B. (1985). Leaders: The Strategies for Taking Charge. NY: Harper \& Row. 
Bhattacherjee, A. (2002). Individual trust in online firms: Scale development and initial test. Journal of Management Information Systems, 19 (1), 211-241.

Bijlsma, K. \& Koopman, P. (2003). Introduction: trust within organisations. Personnel Review, 32 (5), $543-555$.

Blomqvist, K. (1997). The many faces of trust. Scandinavian Journal of Management, 13 (3), 271-286.

Blomqvist, K. \& Ståhle, P. (2004). Trust in technology parternerships. In M. Huotari \& M. Livonen ( Eds.), Trust in Knowledge Management and Systems in Organizations. London: Idea Group Publishing, pp. 173-199.

Brenkert G.G., (1998), Trust, Morality and International Business, in C. Lane \& R. Bachmann (eds.) Trust Within and Between Organizations. Conceptual Issues and Empirical Analysis. Oxford University Press, Oxford, pp.273297.

Brower, H. H., Lester, S. W., Korsgaard, M. A., \& Dineen, B. R. (2009). A closer look at trust between managers and subordinates: Understanding the effects of both trusting and being trusted on subordinate outcomes. Journal of Management, 35 (2), 327-347

Burt, R. S. \& Knez, M. .(1996). Trust and third-party gossip . In R. M. Kramer \& T. R. Tyler ( Eds.), Trust in Organizations: Frontiers of Theory and Research, (pp.68-89). Thousand Oaks, CA: Sage Publications, Inc.

Butler, J. K. (1991). Toward understanding and measuring conditions of trust: Evolution of a conditions of trust inventory. Journal of Management, 17 (3), 643-663

Castaldo, S. (2003, September). Trust variety: Conceptual nature, dimensions and typologies. IPM Conference, Lugano, Switzerland

Castaldo, S. (2003). Trust variety-conceptual nature, dimensions and typologies. IMP 2003 Conference, Lugano, Switzerland (4-6 Sept). [Available at: http://www.impgroup.org/uploads/papers/4317.pdf, Accessed: 09 March, 2009]

Cheng, F., Yeh, C. \& Tu, C. (2008). Trust and knowledge sharing in green supply chains. Supply Chain Management: An International Journal, 13 (4), 283-285.

Chow, S. \& Holden, H. (1997). Toward understanding a loyalty: The moderating role of trust. Journal of Managerial Issues, 9 (3), 275-298.

Davenport, T.H. \& Prusak, L. (1998). Working Knowledge: How Organizations Manage What They Know. MA: Harvard Business School Press.

Dietz, G. \& Hartog, D. N. D. (2006). Measuring trust inside organisations. Personnel Review, Evans, A. M. \& Revelle, W. (2008). Survey and behavioral measurements of interpersonal trust. Journal of Research in Personality, 42, 1585-1593.

Evaristo, J. R. (2007). Knowledge transfer across borders: A process model. Knowledge and Process Management, 14(3), 203-210.

Ford, D. P. (2004). Trust and knowledge management: The seeds of success. In Clyde W. Holsapple (Ed.), Handbook on Knowledge Management 1 Knowledge matters, (pp.553-575), Heidelberg (Germany): SpringerVerlag

Fukuyama, F. (1996). Trust: The Social Virtues and the Creation of Prosperity. NY: Simon \& Schster Inc.

Gefen, D. (2004). What makes an ERP implementation relationship worthwhile: Linking trust mechanisms and ERP usefulness. Journal of Management Information Systems, 21(1), 263-288.

Giffin, K. (1967). The contribution of studies of source credibility to theory of interpersonal trust in the communication department. Psychological Bulletin, 68, 104-120.

Gillespie, N. \& Dietz, G. (2009). Trust repair after an organization level failure. Academy of Management Review, 34 (1), 127-145.

Gutteling, J. Hanssen, L. van der Veer, N. and Seydel, E. (2006). Trust in governance and the acceptance of genetically modified food in the Netherlands. Public Understanding of Science, 15, 103-112.

Hasnain, S. S. (2016). A few good knowledge transfer mechanisms: Keys to successful military operations. Archives of Business Research, 3 (4), 1-8.

Hasnain, S.S. \& Jasimuddin, S. M. (2012). The Barriers to Knowledge Transfer: An Empirical Study in the NonGovernmental Organisations (NGOs) in Bangladesh. World Journal of Social Science, March 2 (2), 135-15. 
Hansen, M. T. (2002). Knowledge networks: Expalining effective knowledge sharing in multiunit companies. Organizational Science, 13 (3), 232-248.

Hardy, C. Philips, N. \& Lawrence, T. (1998). Distinguishing trust and power in interorganizational relations: Forms and facades of trust. In C. Lane \& R. Bachmann(eds.) Trust within and between Organizations, Conceptual Issues and Empirical Analysis, Oxford University Press, Oxford (pp. 64-87)

Hieronymi, P. (2008). The reasons of trust. Australian Journal of Philosophy, 86 (2), 213-236

Hoect, A. \& Trott, P. (1999). Trust risk and control in the management of collaborative Technology development. International Journal of Innovation Management, 3 (3), 257-270.

Hoell, R. C. ( 2004). The effect of interpersonal trust and participativeness on union member commitment. Journal of Business and Psychology, 19 (2), 161-177

Hofer-Alfeis, J. \& van der Spek, R. (2002). The knowledge strategy process: An Instrument for business owners. In T. H. Davenport \& G.J.B. Probst (Eds.) Knowledge Management Case Book: Siemens Best Practices (pp. 24-39). Erlangen: Policies Corporate Publishing \& John Wiley \& Sons.

Hogberg, C.\& Edvinsson, L. (1998). A design for futurizing knowledge networking. Journal of Knowledge Management, 2 (2), 81-92.

Holsapple, C. W. \& Jones, K. (2006) 'Knowledge management strategy formation , in Schwartz, D.G.(ed.) Encyclopaedia of Knowledge Management. London: Idea Group Reference. pp. 419-428.

Holste, J. S. (2003). A Study of the Effects of Affect-Based Trust and Cognition-Based Trust on Intra-Organizational Knowledge Sharing and Use. PhD thesis (unpublished), Regent University

Holste, J. S. \& Fields, D. (2010). Trust and tacit knowledge sharing and use. Journal of Knowledge Management, $14(1), 128-140$

Johnson-George, C. \& Swap, W. C. (1982). Measurement of specific interpersonal trust: Construction and validation of a scale to assess trust in a specific other. Journal of Personality and Social Psychology, 43 (6), 1306-1317.

Kasper-Fuehre, E. C. \& Ashkanasy, N. M. ( 2001). Communicating trustworthiness and building trust in interorganizational virtual organizations. Journal of Management, 27, 235-25.

Katz, H. A. \& Rotter, J. B. (1969). Interpersonal trust scores of college students and their parents. Child Development, 40(2), 657-661.

Kee, H. W. \& Knox, R. E. (1970). Conceptual and methodological considerations in the study of trust. Journal of Conflict Resolution, 14, 357-366.

Kerkhof, P., Winder, A. B., Klandermans, B. (2003). Instrumental and relational determinant of trust in management among members of works council. Personnel Review, 32 (5), 623-637.

Kipnis, D.(1996). Trust and technology . In R. M. Kramer \& T. R. Tyler ( Eds.), Trust in Organizations: Frontiers of Theory and Research, (pp.39-50). Thousand Oaks, CA: Sage Publications, Inc.

Ko, D. (2010).Consultant competence trust doesn't pay off, but benevolence trust does! Managing knowledge with care. Journal of Knowledge Management, 14(2),

Kramer, R. M. (1999). Trust and distrust in organisations: Emerging perspectives, enduring questions. Annual Review of Psychology, 50, 569-598.

Kramer, R. M .(1996). Divergent realities and convergent disappointments in the hierarchic relation: Trust and intuitive auditor at work . In R. M. Kramer \& T. R. Tyler (Eds.), Trust in Organizations: Frontiers of Theory and Research, (pp.216-245). Thousand Oaks, CA: Sage Publications, Inc.

Levin, D. Z. \& Cross, R. (2004). The strength of weak ties you can trust : the mediating role of trust in effective knowledge transfer. Management Science, 50 (11), 1477-1490

Levin, D. Z., Cross, R. Abrams, L. C. \& Lesser, E. L. (2002). Trust and knowledge sharing: A critical combination. IBM Institute of Knowledge Based Organisation. Available at: http://www-935.ibm.com/services/nz/igs/pdf/g5101693- 00- cpov- trust-and-knowledge-sharing.pdf. Accessed: 5 December, 2009.

Levin, D. Z., Whitener, E.M. \& Cross, R. (2006). Perceived trustworthiness of knowledge sources : The moderating impact of relationship length. Journal of Applied Psychology, 91(5), 1163-1171. 
Lewicki, R. J. \& Bunker, B. B. (1996). Developing and maintaining trust in work relationship . In R. M. Kramer \& T. R. Tyler (Eds.), Trust in Organizations: Frontiers of Theory and Research, (pp.114-139). CA: Sage Publications

Lewicki, R. J., Mcallister, D. J. \& Bites, R. J. (1998). Trust and distrust: New relationships and realities. Academy of Management Review, 23 (3), 438-458.

Lewis, D. J. \& Sobhan, B. (1999). Routes of funding, roots of trust? Northern NGOs, southern NGOs, donors, and the rise of direct funding. Development in Practice, 9 (1\&2), 117-129.

Lewis, D. J. \& Weigert, A. (1985). Trust as a social reality. Social Forces, 63(4), 967-985.

Li, L. (2005). The effects of trust and shared vision on inward knowledge transfer in subsidiaries' intra-and interorganizational relationships. International Business Review, 14, 77-95

Lewicki, R. J.\& Bunker, B., (1995). 'Trust in relationships: a model of trust development and decline'. In B. Bunker, \&J. Rubin (Eds.), Conflict, cooperation and justice, (pp. 133-173). San Franscisco: Jossey-Bass

Lucas, L. M. (2005). The impact of trust and reputation on the transfer of best practices. Journal of Knowledge Management, 9 (4), 87-101

Luhmann, N. (1979). Trust and Power. Chichester: John Wiley \& Sons

Luhmann, N. (1988). Familiarity, confidence, trust: Problems and alternatives. In D. G. Gambetta (Ed.), Trust: 94107.

Luhmann N., (1989). Familiarita', confidare e fiducia: problemi e alternative, in Gambetta D. (ed.),Trust. Making and Breaking Cooperative Relations, Basil Blackwell Ltd., Oxford

Ma, Z., Qi, L. \& Wang, K. (2008). Knowledge sharing in Chinese construction project teams and its affecting factors: An empirical study. Chinese Management Studies, 2(2), 97-108ff.

Mayer, R. C., Davis, J. H. (1999). The effect of performance appraisal system on trust for management: A field quasi-experiment. Journal of Applied Psychology, 84 (1), 123-136.

Mayer, R.C., Davis, J.H. \& Schoorman, F.D. (1995). An integrative model of organizational trust. Academy of Management Review, 20 (3), 709-734

McAllister,D.J. (1995).Affect- and cognition-based trust as foundations for interpersonal cooperation in organizations. The Academy of Management Journal, 38(1), 24-59.

McEvily, B., Perrone, V. \& Zaheer, A. (2003). Trust as an Organizing Principle. Organization Science, 14 (1), $91-103$.

McKnight, D. H. \& Chervany, N. L.(2001-2002, Winter). What trust means in e-commerce customer relationships: An interdisciplinary conceptual typology. International Journal of Electronic Commerce, 6 (2), 35-59.

McKnight, D. H., Cummings, L. L. \& Chervany, N. L. (1998). Initial trust formation in new organizational relationships. The Academy of Management Review, 23 (3), 473- 490.

Meyerson, D. Weick, K. E. and Kramer, R.M. (1996). Swift trust and temporary groups. In R. M. Kramer \& T. R. Tyler (Eds.), Trust in Organizations: Frontiers of Theory and Research (pp.166-195), Thousand Oaks, CA: Sage Publications, Inc.

Michael, S. (2002). The Role of NGOs in Human Security. The Hauser Centre for Non-profit Organizations (Harvard University), Working Paper No. 12

Miles, M. B. \& Hurberman, M. (1994). Qualitative Data Analysis. CA: Sage Publications, Inc.

Mintzberg, H. (1973). The Natural of Managerial Work. NY: Harper and Row

Mishra, A. K.(1996). 'Organizational response to crisis: The century of trust', in R. M. Kramer \& T. R. Tyler ( eds.), Trust in Organizations: Frontiers of Theory and Research, California: Sage Publications, pp. 261-287.

Morgan R.M. \& Hunt S.D., (1994). The Commitment-Trust Theory of Relationship Marketing. Journal of Marketing, 58 (july), 20-38.

Muir, M. \& Mory, N. (1996). Trust in automation, part-II: Experimental studies of trust and human intervention in a process control simulation. Ergonomics, 39, 429-460

Nahapiet, J. \& Ghosal, S. (1998). Social capital, intellectual capital, and the organizational advantage, The Academy of Management Review, (2) 23, 242-266.

Ngah, R., Hoo, C. H. \& Ibrahim, A. R. (2008). The relationship between knowledge management and trust: Malaysian perspective. Communication of the IBIMA, Vol. 4, 113-119. 
Nonaka, I. \& Takeuchi, H. (1995). The Knowledge Creating Company. Oxford: Oxford University Press.

Nooteboom, B. (1996). Trust-based forms of governance: A process and control model. Organization Studies, 17, 985-1010.

Nooteboom, B., Berger, H. \& Noorderhaven, N. G. (1997). Effects of trust and governance on relational risk. The Academy of Management Journal, 40 (2), 308-338

Olen, J. (1976). Is undefeated justified true belief knowledge? Analysis, 36 (3), 150- 152. Parks, C. D., Henager, R. F. \& Scamahorn, S. D. (1996). Trust and reactions to messages of intent in social dilemmas. The Journal of Conflict Resolution, 40 (1), 134-151.

Peterson, R. (1998). Trust for quality. The TQM magazine, 10 (6), 413-416.

Politics, J. D. (2003).The connection between trust and knowledge management: What are its implications for team performance. Journal of Knowledge Management, 7 (5), 55-66.

Poppo, L., Zhou, K. Z. \& Ryu, S. (2008). Alternative origins to internationalizational trust: An interdependence perspective on the shadow of the past and the shadow of the future. Organization Science, 19 (1), 39-55.

Powell, W. W.(1996). Trust-based forms of governance. In R. M. Kramer \& T. R. Tyler (Eds.), Trust in Organizations: Frontiers of Theory and Research, (pp.51-67). Thousand Oaks, CA: Sage Publications, Inc.

Rempel, J. K., Holmes, J. G. \& Zanna, M. P. (1985). Trust in close relationships. Journal of Personality and Social Psychology, 49 (1), 95-112.

Renzl, B. (2008). Trust in management and knowledge sharing: The mediating effects of fear and knowledge documentation. Omega, 36(2), 206-220.

Rolland, N. \& Chauvel, D. (2000). Knowledge transfer in strategic alliances. In C. Despres \& D. Chauvel (Eds.), Knowledge Horizons: The Present and Promise of Knowledge Management (pp. 225-236), Boston, MA: Butterworth-Heinemann

Rotter, J. B. (1967). A new scale for measurement of interpersonal trust. Journal of Personality, 35 (4), 651-665.

Rotter, J. B. (1980). Interpersonal Trust, Trustworthiness, and Gullibility. American Psychologist, 35 (1), 1-7

Rousseau, D. M., Sitkin, S. B., Burt, R. S. and Camerer, C. (1998). Not so different after all: A cross discipline view of trust. The Academy of Management Review, 23 (3), 393-404.

Sako, M., (1992). Prices, Quality and Trust. Inter-firm Relations in Britain and Japan. Cambridge: Cambridge University Press

Sako, M. \& Helper, S. (1998). Determinants of trust in supplier relations: Evidence from the automotive industry in Japan and the United States. Journal of Economic Behavior \& Organization, (34), 3, 387-417

Sankowska, A. (2013). Relationships between organisational trust, knowledge transfer, knowledge creation, and firm's innovativeness. The Learning Organisation, 20(1), 85-100.

Scarbrough, H. (1995). Blackboxes, hostages and prisoners, Organization Studies, 16 (6), 991-1019.

Sheppard, B. H. \& Sherman, D. M. (1998). The Grammars of trust: A model and general implications. The Academy of Management Review, 23 (3), 422-437.

Sheppard, B. H. \& Tuchinsky, M. (1996). Micro-OB and the network organization. In R. M. Kramer \& T. R. Tyler ( Eds.), Trust in Organizations: Frontiers of Theory and Research, (pp.140-165). Thousand Oaks, CA: Sage Publications, Inc.

Singh, T. \& Premarajan, R. K. (2007). Antecedents to knowledge transfer: Trust and culture. South Asian Journal of Management, 14 (1), 93-104.

Smith, J.B., Barclay, W.B. (1997). The effects of organizational differences and trust on the effectiveness of selling partner relationships. Journal of Marketing, 61 (1), 3-21

Smyth, H., Gustafsson, M. \& Ganskau, E. (2010). The value of trust in project business. International Journal of Project Management, 28, 117-129.

Sobhan, S. (2000). Legal aid. In M. Ahmad (Ed.), The Other Option: NGO's and People's Praxis, (pp. 85-101). Dhaka: Community Development Library 
Soh, H. Reid, L.N. \& King, K. W. (2007). Trust in different advertising media. Journalism and Mass Communication Quarterly, 84 (4) (Autumn), 455-476.

Sreckovic, M. \& Windsperger, J. (2012). The Impact of Trust on the Choice of Knowledge Transfer Mechanisms in Clusters (January 6, 2012). Network Governance: Alliances, Cooperatives and Franchise Chains, Ehrmann, Th., Windsperger, J., Cliquet, G., Hendrikse, G. (Eds.), Springer Verlag: Berlin Heidelberg, 2013, p. 73 - 85. Available at SSRN: http://ssrn.com/abstract $=2637263$

Staples, D. S. \& Webster, J. (2008). Exploring the effects of trust, task interdependence and virtualness on knowledge sharing in teams. Information Systems Journal., 18, 617-640.

Stein, E. W. (1995). Organizational memory: Review of concept and recommendations for management. International Journal of Information Management, 15 (2), 17-32.

Sztompka, P. (1999). Trust: A Sociological Theory. Cambridge: Cambridge University Press

Szulanski,G., Cappetta, R. \& Jensen, R.J.(2004). When and how trustworthiness Matters: Knowledge transfer and the moderating effect of casual ambiguity. Organization Science,15 (5), 600-613.

Taiwana, A. (2002). The Knowledge Management Toolkit: Practical Techniques for Building a Knowledge Management System. NJ: Prentice Hall.

Tallman, R. (2007). Does trust matter? : Perceptions, trust and job satisfaction of hospital nurses. International Journal of Business Research, 7 ( (4), 166-174.

Tsai, W. \& Ghoshal, S. (1998). Social capital and value creation: The role of intra firm networks. Academy of Management Journal, 41(4), 464-476.

Tschannen-Moran, M. (2001). Collaboration and the need for trust. Journal of Educational Administration, 39 (4), 308-331.

Tyler, T. R. \& Kramer, R. M.( 1996). Whither trust. In R. M. Kramer \& T. R. Tyler ( Eds.), Trust in Organizations: Frontiers of Theory and Research (pp.1-15), Thousand Oaks, CA: Sage Publications, Inc.

Uggirala, A., Gramopadhye, A., Melloy, B. \& Toler, J. E. ( 2004). Measurement of trust in complex and dynamic systems using a quantitative approach. International Journal of Industrial Ergonomics, 34, 175-186.

Usoro, A., Sharratt, M. W., Tsui, E. \& Shekhar, S. (2007). An inVaustment into trust as an antecedent to knowledge sharing in virtual communities of practice. Knowledge Management Research and Practice, 5, 199-212

Webb, E. J.(1996). Trust and crisis. In R. M. Kramer \& T. R. Tyler (Eds.), Trust in Organizations: Frontiers of Theory and Research, (pp.288-301). Thousand Oaks, CA: Sage Publications, Inc.

Weber, R. P. (1985). Basic Content Analysis. London: Sage Publications Ltd.

Whitener, E. M., Brodt, S. E., Korsgaard, M.A. \& Werner, J. M. (1998). Managers as initiators of trust: An Exchange relationship framework for understanding managerial trustworthy behavior. The Academy of Management Review, 23 (3), 513-530

Wicks, A. C., Berman, S.L., Jones, T. M. (1999). The structure of optimal trust: Moral and Strategic Implications. The Academy of Management Review, 24 (1), 99-116.

Williamson, O. E. (1993). Calculativeness trust, and economic organisation. Journal of Law and Economics, 36, 453-486.

Zucker, L.G., (1986). Production of trust: Institutional sources of Economic structure, 1840-1920. Research in Organisational Behaviour, 8, 53-111

Zucker, L. G., Darby, M. R., Brewer, M. B., Peng, Y. (1996). Collaboration structure and information dilemmas in biotechnology: Organizational boundaries as trust production . In R. M. Kramer \& T. R. Tyler ( Eds.), Trust in Organizations: Frontiers of Theory and Research, (pp.90-113). Thousand Oaks, CA: Sage Publications, Inc 